\title{
THE SCOPE OF THEOLOGY AND ITS PLACE IN THE UNIVERSITY.
}

By CHARLES A. BRIGgs, New York.

ThE development of theological education in the United States of America has been in three stages (I) in the college; (2) in the professional school ; (3) in the professional school in alliance with, or in organic union with, the university. We have only recently entered upon the third stage and theological education in the immediate future will advance in university lines.

The American colleges have been gradually casting off the bonds of ecclesiasticism and dogmatism which enslaved them to denominationalism and made them the citadels and prisons of sectarianism. The elimination of the theological seminary from the college removed the chief difficulties in the way of the liberation of the college: but at the same time it resulted in increasing the bondage of the theological seminaries; so that these became the strongholds not merely of denominationalism but of schismatic tendencies in the denominations themselves. The theological seminary may gain its freedom either by a gradual appropriation of the spirit and life of the university with which it may be affiliated or by itself throwing off the bondage of denominationalism and sectarianism and becoming a theological university. The former is the easier and simpler method, the latter is the more difficult and complex; but on this very account possibly the more fruitful. If the two methods could combine, the best results would be attained. The theological seminary is entering into closer relations with the university in many of the great cities of our land. These relations are of very great importance both to the university and to the theological school. There are opportunities of mutual helpfulness and also of mutual injury. On the one hand it would be a calamity if any of our great universi- 
ties should take the theological seminary to its bosom, warm the serpent of sectarianism into new life and give it such an influence in the university body as to again imperil the freedom of the university. The university should guard its freedom by perpetual vigilance lest it again put on the bonds of denominationalism. On the other hand there is peril to the theological seminary lest it merge itself and become lost in the larger life of the university.

The theological seminaries which have enjoyed the greatest prosperity and have had the largest number of students and the most extensive public influence during the last thirty years have been the theological seminaries which have stood apart as independent institutions. Several of the older colleges have grown into universities with theological faculties. But the most of the American universities are without theological faculties, either by original design to avoid sectarian complications, or else for the reason that they have grown into universities from schools of arts and sciences, without provision for theological instruction. Both these universities and the theological seminaries have been greatly injured by this separation and they have much to gain by a reunion.

The university, so long as it has no theological school, cannot be a real university, because it neglects one of the four faculties of the historic university; because it does not recognize that department of learning which is the highest, the deepest, the most comprehensive, and the most far-reaching of all. Theology is and must always be the mother and queen of the sciences. All the sciences spring from theology as their common mother - they tend to theology as their common goal. Theology is the science of God in his own being and in all his relations. As God is supreme over all, the fountain of being, the spring of all movement, the end of all the evolutions of nature, the science of God is the comprehensive science, and theology is the universal science. Apart from the universal science there can be no real university. An institution of learning without theology is not and cannot be a real university. A real university must be a theological university, not theological 
in the restrictive sense of merely giving professional theological training but in as comprehensive a sense as university itself, embracing all departments of learning.

A. THE RELAtion OF Other UNIVERSity STUdies to THEOlogy.

The various departments of instruction in the university cannot accomplish their full purpose unless they are in touch with theology, which underlies them, pervades them, and beckons them on. We shall consider several departments as specimens.

I. Philology.-( I) The colleges teach the ancient classic Latin language and literature. This is important for general culture to make an educated man. But the great mass of Latin literature is subsequent to the classic literature and is chiefly ecclesiastical and legal. The Latin department in the university must advance into the field of ecclesiastical and legal Latin, or else the Latin departments in the colleges will be only preparatory schools in Latin to the theological seminary and the school of law where the later and more extensive ecclesiastical and legal Latin are used. In olden times all educated men were taught to speak Latin and to read it at sight. Now more attention is paid to the finer qualities of the language and literature, and few college men can read Latin at sight; fewer still can speak it and write it. It is to be feared that our colleges overlook the fact that professional men need ecclesiastical and legal Latin much more than the classic Latin; and that for their purposes the ability to read simple Latin prose at sight is the main thing, the lack of which cannot be atoned for by any amount of study of the masters of classic Latin literature and style.

(2) The Greek department may teach the ancient classic Greek language and literature, but if it neglect the Hellenistic Greek with its valuable literature, and the Byzantine Greek with its enormous literature, can it truly be said to be doing the work of the university? It will be only a preparatory school in Greek to that professional school which will give instruction in the Hellenistic Greek and in the Byzantine Greek. For the purposes of the theologian a very different course of study in Greek is required from that taught at present in our colleges. 
The New Testament professor finds that his students coming from college or university are not sufficiently prepared in the Greek language to understand the Greek of the New Testament. The reasons are probably that so large a proportion of college students do not take Greek in the Junior and Senior years; or, if they pursue their studies in Greek it is in the more difficult poets and dialects which do not increase their ability to read Greek prose, and they forget the technical rules of grammar. It is necessary as things now are, in the Junior class in the theological school to review the study of the elements of Greek grammar and to give the instruction in Hellenistic Greek which college students ought to bring with them from college. As things now are, the college graduate is far from that knowledge of Greek which the study of theology requires.

(3) It is well known that the American universities have done very little for Semitic languages. And yet these languages are of immense importance in many branches of learning. The Hebrew language is the language of the Old Testament Scriptures and of the Mishna, the fundamental law code of the Hebrews. The Syriac is the language of the earliest version of the New Testament and of an extensive literature which is of great importance for many different branches of learning. The Arabic is the richest and most comprehensive in vocabulary of all languages, spoken by more people at the present than any other; giving the literature of one of the greatest of the religions of the world; one of the most important of the sacred books, the Koran; the choicest collection of tales, the Thousand and One Nights; and a literature whose extent in poetry and history, in philosophy and in science vies with those of the Greeks and Latins. The Aramaic with its Talmuds and rabbinical literature based thereon, is an ocean of learning, in some respects the most prolific in the Middle Ages. The Assyrian with its brick libraries, revealing the literature, history, and religion of the ancient world, where lie the roots of the civilizations of Greece and of Palestine, is so extensive at the present time in the museums of the world and increases so rapidly with fresh discoveries that it is estimated there are not assyriologists in the world sufficient in number to 
decipher the tablets for years to come. The theological schools are in a measure doing the work in these Semitic fields which our great universities ought to do. Thus far few universities have a Semitic department, and these are doing chiefly elementary work. Few of them give elementary instruction even in Hebrew. In the whole Semitic department at present university work is to be sought in the theological seminaries more than in the American universities.

The professors in theological seminaries who work in the Old Testament are obliged to teach the elements of the Hebrew language, and therefore so large an amount of valuable time is consumed in preparation for the study of the Old Testament that it is difficult within the limits of the three years' course to give the average student a sufficient acquaintance with the entire Old Testament to enable him to continue his studies and to maintain the grade already gained, in the midst of the difficulties and perplexities of ministerial life. The colleges ought to give instruction in the Hebrew language, and it ought to be presupposed and required as a condition of entrance upon a theological course. For the purposes of theological education it is more important that the colleges should give this study to students who have theology in view than many other things that are regarded as essential to the college course. Our colleges should offer courses in Greek and Hebrew in the Junior and Senior years as electives for theological students which will prepare them for the work in the Hebrew of the Old Testament and in the Greek of the New Testament. If this could be done it would in effect give an additional year to the study of the Bible in the original languages, and would double the training of theological students in the original Scripture.

The languages of the far East are also of some importance to the theological seminary. The languages and literatures of India, Persia, China, and Japan are necessary acquirements to missionaries, merchants, or scholars who would pursue their callings in these countries, and also for students of the ancient religions. Thus in the whole department of philology the theological seminary asks much more of the universities than they are doing. 
II. History.-History comes into contact with theology at every step. Even the histories of Greece and Rome ought not to neglect the mythology, the religious beliefs and ceremonies and the ethics of those great races of antiquity. The history of the Hebrews is essentially religious history. Nothing can be done with the histories of Egypt, Assyria, Babylonia, Phœnicia, and Persia without knowing their religions, their doctrines, and their morals. The same is true of the history of the nations of Eastern Asia, China, India, Corea, Siam, and Japan. The history of the world since the advent of Jesus Christ is dominated by Christ and Christianity. If the historians in the universities teach history without giving Christ and Christianity their place and importance, they do not teach real history, but a very partial and one-sided history. That history must be a very small affair which leaves out the history of the Jews, the life of Christ and his apostles, the history of the Christian Church, and the religious development of the heathen world. In point of fact the average student, who comes with a bachelor's degree from our colleges and universities to the seminaries, comes without a sufficient knowledge of general history and its principles to give him the proper preparation for the scientific study of church history. At the present time the theological seminary is the university for the department of history in many of its most important sections. The philosophy of history lies at the root of all biblical history and church history. How few of our universities know of it! The theological seminary as it advances to the study of the ethnic religions enlarges its scope from biblical history to universal history. Where shall the universal history of the future be taught-in the so-called university which neglects theology or in a theological seminary which has been transformed into a theological university?

III. Philosophy.-In the theological seminary the department of systematic theology is dependent in large measure upon the teaching in the colleges in the department of philosophy. The graduates of our colleges, on the average, have not that elementary training in psychology, metaphysics, and ethics needed to begin the study of systematic theology. In fact the question has 
been under consideration whether there should not be a preparatory year in the theological seminary in order to give that instruction which is not given at present in our colleges, and which theological students need preparatory to their theological studies.

The theological seminaries are deeply interested in all ethical and sociological questions at the present time. New professorships are being established. Others are in contemplation. There is danger lest the practical side should outbalance the scientific side and so crude and wasteful enterprises be undertaken. The university may greatly aid the theological seminary at this crisis. But it can aid it only by looking at these matters in such a comprehensive way as will satisfy the interests of the theologian as well as the interests of scientific investigation and statement. In the near future will the university supply these needs of the theological seminary and so bind it to the university, or will the theological seminary in its own interest be compelled to enlarge these departments?

IV. Physical Sciences.-Theology has thus far had the least connection with the physical sciences. But the time is at hand when theology will be so reconstructed in accordance with a sound and comprehensive view of nature and a true theory of the universe that the whole realm of nature and the physical sciences will come within its sweep and contribute to the solution of its problems.

Astronomy raises the question whether there are other worlds than ours - other worlds inhabited by intelligent beings - other sinful creatures - others who need atonement and salvation. A theology which was constructed in view of the history and civilization of Western Asia, Northern Africa and Europe, a small portion of our earth, is reconstructing itself in view of the whole of our world. But how much greater that reconstruction will be so soon as astronomy can tell us with decision that there are other worlds of beings like ourselves. Every department of theology will transform itself in order to comprehend such new knowledge of God and his universe.

The sciences which unfold the history of life on our globe, 
and of the globe itself, have destroyed the old forms of dogma as to the origin and early history of the earth and man. There are scientific men who try to explain the early chapters of Genesis in accordance with the results of modern science. But most biblical scholars refuse to misinterpret the records of Holy Scripture. They prefer to face the facts of the discrepancy between the stories of Genesis and the results of science. The more the real situation becomes a part of the common property of theologian and of student of nature, the greater will be the transformation in theology resulting therefrom.

There is at present a disinclination both on the part of men of physical science and of theologians to discuss theology in relation to physical science. But the time is at hand when a master in physical science will strike the keynote, and a chorus will burst forth from universal nature in the Benedicite of a new theologynew in form because transformed by a more comprehensive view of God and of man and of nature, and yet old in substance because it is the science of the same God over all, blessed forever.

Will the theological seminary be obliged to do this work, and so become the university for the physical sciences also, or will the university enlarge itself as a real university to do this work for theology and so bind the theological school to itself in bonds of everlasting obligation?

V. Medicine.-The higher branches of medicine are coming into closer connection with theology than ever before. Dr. Wm. Adams, once president of the Union Seminary, gave it as his opinion, after a long life of pastoral experience, that a large amount of morbid religious experience was due to diseases of the body. He took pains that the theological students under his care should have frequent lectures from eminent physicians on these subjects. It is quite evident that the work of the pulpit is determined to a great extent by the condition of the liver, and the circulation of the blood, by the temperament and physical habits of the minister. The observance of the laws of health and the prevention of disease cannot be accomplished by the medical faculty alone; they need the help of the theologian and 
the preacher to reinforce medical laws by moral and religious sanctions. Faith Cure, so-called, has not won public confidence. Christian Science seems to misname itself in both noun and adjective. But the advocates of these methods are earnest Christian people who are laying stress upon an important principle which has been too much neglected by both the medical and the theological faculties, namely, that cures depend to a very great extent upon gaining the confidence of the patient, so that faith in the physician or in a fictitious remedy may sometimes accomplish more than a real remedy when accompanied by disbelief in its efficacy. Here medicine comes into the field of religion where theology and medicine should work in harmony for the solution of its problems.

The new science of hypnotism has an important influence upon theology as well as upon medicine and psychology. There are those who claim that all the biblical and ecclesiastic miracles and prophecies may be explained by the phenomena of the new science. This theory will attract great attention ere long. If hypnotism may be used for medical therapeutics, why not for the healing of religious maladies also? Theology cannot safely be ignored in this investigation. It will study the phenomenon in its own way.

These are but a few of the many ways in which theology and medicine come together. They give an intimation of what the medical faculty might do for the theological faculty. It is not unlikely that the theological faculty might repay the medical faculty in good measure if they would give them an opportunity. There is a border-land of great importance for them both. There are bridges which the university might man with helpful teachers.

VI. Law.-Law is the common field of church and of state. Civil and ecclesiastical law are sometimes parallel, often identical - largely having the same origin and development. The legislation contained in the Pentateuch has exerted a powerful influence upon all the ages. The history of its legislation, as determined by the modern biblical criticism, has set that legislation in a new and important light which cannot be safely disregarded by the legal faculty. It sheds light upon legal and social questions in 
our day. In the Roman Catholic church canon law is one of the most important of theological studies. It is recognized in the universities of Europe. But in American theological schools it has been ignored. There is usually instruction in the principles of church government and discipline and the practice of the denomination. But the history of canon law, its institutes and its practice are little known. That is the reason why American ecclesiastical bodies are so often nothing more than conventions carried by popular majorities under the impulse of ecclesiastical demagogues who have no interest in law but are only concerned for their party. There can be little stability, or orderly procedure in the church unless the canon law, which is the product of centuries of ecclesiastical experience, is known and followed. The canon law is older than modern denominations. It is closely associated with civil law in its development. The university may greatly aid the theological seminary by giving instruction in it.

The minister and the lawyer are alike concerned with domestic relations. Marriage is a civil and a religious institution. The care of children, their education and their rights, the duties of husband and wife, of master and servant - all these are theological questions as well as civil questions. They may be viewed as sociological questions, or as questions of civil, or of ecclesiastical law and practice. It is of great importance that the theologian should know these matters in their civil relations and that the jurist should know them in their ecclesiastical and ethical relations. Here is a bridge on which a university professor should take his stand and mediate between the legal and the theological faculties.

Questions of property are ecclesiastical questions also. It is not equitable to consider them merely in their civil relations. Great injustice is often done in our country because of the reluctance of the judges to consider questions of ecclesiastical right, and of their ignorance of ecclesiastical relations. The church may be a religious club in the eyes of the civil law; but it is in fact more than a religious club and its historic right is more ancient than any of the modern states. The civil law cannot deal 
with the church as a mere social club of yesterday, without at times doing grave injustice and wrong to the most important interests of mankind. The ultra-protestant point of view which dominates common law in America often does injustice to great historic interests. The Roman church is entitled to great sympathy in its grave difficulties in our country. It cannot be that it should yield its ancient and venerable laws to the legal maxims of yesterday or today without a struggle.

The legal rights of clergymen and the laws relating to ecclesiastical property are of great importance in the administration of ecclesiastical affairs. The university has an obligation to give instruction in this department and to train a sufficient number of men, either lawyers or ministers, who may be competent to consider all the intricate questions which may arise in these relations. Law and theology are so entwined that there ought to be a considerable number of lawyers and ministers who may be able to take a comprehensive view of both departments.

The present situation in our country as regards the relation of the school to the church and state is an unstable situation. The three great interests are entwined and they cannot be untwined without serious damage to them all. There are areas of independence for each department. But there are also inevitable points of contact and interdependence between the three. Neither the church nor the state can safely take hands off from the school. Theology cannot possibly exclude the school or the state any more than the family and the church from the scope of its learning and teaching and activities. The theologian will be blind to important interests if he looks only at the churchly side. The lawyer will be still more blind if he looks only at the side of civil and political law. Comprehensive study of both sides-of all sides-of these questions is needed, and the university is the proper place for it. Our country is in great peril just at this point. There is one-sidedness in almost all discussions of these subjects.

We have shown that the great departments of learning in the university lead up to theology and that there are bridges uniting them, or rather vital organs connecting them, with their mother 
theology. The disjoining of university and theological school has been mischievous in the main, though it has been productive of some minor temporary advantages. The neglect of the theological bearings of the other sciences dwarfs them all. That is one of the reasons of the agnosticism of some of our universities. The teachers pursue their studies until theology or the Bible come within their bearing; then, instead of facing the Bible and theology and working out the questions in their own department in view of Bible and church, honestly seeking alone the truth of God whether there be conflict or not; they either, following the interpretation of traditional dogma, see the conflict and timidly withdraw from further consideration of delicate and dangerous problems ; or, seeing the conflict, advance boldly and without discrimination to attack Bible and church; or, in simple agnosticism, abstain from further study of the unknown and the supposed unknowable. This dwarfs the sciences by retarding their development in one direction after another. But it also does grave injustice to theology which needs all the light that every department of science can give it ; which, notwithstanding all the outcries of the ignorant and the bigoted, welcomes every contribution of learning; and which is able to transform itself under the guidance of the divine Spirit and adapt itself in every age to every truth and every fact, to the whole universe of reality.

Thus in all its departments the university leads up to theology - it cannot gain completeness in any of them without theology. This is the reason why so many universities have been organized in recent years under the control of the great religious sects. The state universities generally, ignore theology, not only by omitting a theological faculty, but also by avoiding theological questions when they arise in the other faculties. This ignoring of theology gives the appearance of agnosticism even when it does not really exist. The state universities cannot fairly be charged with agnosticism and yet from the circumstances in which they are placed they seem to be obliged to avoid theology. Accordingly we see springing up in our land Roman Catholic universities, Methodist universities, Baptist universities, Presbyterian universities, and so on. Such universities aim to be not simply 
theological universities, but denominational and sectarian universities. This can only be regarded as a decline from the true ideals of education. The theological faculty should be relieved from the bondage of ecclesiasticism and sectarianism. Theology is a science, the queen of the sciences, and should be studied and loved as such. It will be no gain to theology to enslave the other faculties. It will not make a university theological to denominationalize all learning. A true university will rise above all denominationalism and sectarianism. A scientific theology will animate and pervade, hallow and glorify all departments of learning.

\section{B. THE DEVElopment OF THEOLOGY IN THE UNIVERSiTy.}

We have been looking at the study of theology from the point of view of the university and have shown that all the departments of the university are so interrelated to theology that they cannot do their full work without theology. We are now prepared to look at the study of theology from the point of view of the theological seminary. The theological seminary has been limited and cramped by shutting itself off from university life. Theology is so transforming itself that it is bursting through these limitations. It is reaching out in all directions and demands the larger, freer life of the university.

Theological encyclopædia is deeply concerned with the classifications and methods of theological science. The common classification for our generation has been ( I) Exegetical theology; (2) Historical theology ; (3) Systematic theology ; (4) Practical theology. This was a convenient classification for a long time; but it was not born either of inductive or deductive logic, or of historic genesis. It was made for convenience. Therefore, with the more recent transformations of theology and the rich development of branches in all directions, the classification is no longer convenient. Why call the range of biblical study exegetical theology? The historian must make an exegesis of his sources, the dogmatic theologian must make an exegesis of the creeds, confessions, and dogmatic treatises. In practical theology the liturgies and the hymns and the historic homilies 
and catechisms must be expounded. Exegesis pervades all departments. Church history is no more historical theology than biblical history, and what can you do in apologetics without the history of religions, or in dogmatics without the history of dogma, or in homiletics without the history of preaching? History also pervades all these departments. Is dogmatic theology to arrogate to itself the exclusive predicate of systematic? Is there no practical theology apart from preaching and pastoral work, from catechisms and liturgies? These adjectives are not distinctive or even characteristic of different departments of theology.

It is not proposed to present a new classification of theology, or to discuss others which have been suggested. Attention is called to the fact that theology is so transforming itself that it is no longer possible to include its wealth of learning in any of the proposed classifications.

At the threshold of the study of theology there should be a general survey, a systematic outline and guide to its several departments. This study is the discipline named theological encyclopædia and methodology or propædeutics. It is indeed a general introduction to theology. This discipline is taught in most German universities. But this study is conspicuous by its absence from the catalogues of most theological schools in our country.

I. The student of Christian theology usually begins with the study of the Holy Scriptures. The greater portion of the time devoted to this department is given to an elementary study of the original languages of the Scriptures. Little time is left for the study of the Scriptures themselves. That is the reason why the ministry in the American churches know so little about their Bibles. In recent years the study of the Bible has been transformed in many of our theological schools, so much so that we have a new Bible. It is new, because it is enveloped in a new light and a new meaning. The older study of the Bible was dominated by dogmatic theology. Everywhere in the Bible the student was taught to interpret by the rule of faith, that is, the traditional dogmatic opinion of his sect; and so he always saw 
in the Bible his rule of faith, nothing more, nothing else. Now the student is taught to study his Bible by scientific principles of interpretation and to correct the rule of faith by the Bible. The Bible is dominant, the rule of faith is subordinate, and so subordinate that it is sinking in the ocean of biblical learning. The study of Holy Scripture opens up fruitful fields of study in many directions.

(I) The study of the canon comes first, for we must determine what are the Holy Scriptures before we can study them in detail as Holy Scripture. This involves a history of the canon, a determination of the successive layers in which the canon was framed, the laws which determined its formation, and the principles by which we may determine its correctness and decide the questions which have ever been in dispute.

(2) The study of the text is a difficult, intricate, and complex work. The original manuscripts, versions, and their citations in ancient writers must all be carefully collected, arranged in the order of their historic genesis; and so we must work our way back to the parent reading, the original words themselves. No one can form any conception of the enormous labor involved in this work. In the New Testament it is sufficiently difficult in the collection of the readings from the great uncials and the cursives, the examination of the early Syriac, Latin, and other versions, and the citations in the fathers and early ecclesiastical writers. The labors of a number of modern scholars, such as Tischendorf, Westcott and Hort, and Gregory have opened up great highways for their successors. But the textual criticism of the Old Testament is a vastly greater work, in which large numbers of modern scholars are now engaged. They need the assistance of learned men in all departments. The professors of Greek have as great interest as the theologians in the text of the Greek Septuagint version of the Old Testament. The professor of history shares with them an interest in the text of Josephus. The philosopher joins them in the study of the text of Philo. The professor of oriental languages has a joint interest in the Syriac version, the classics of the Syriac language, and the Syriac and Ethiopic pseudepigrapha. The Hebrew 
and Aramaic scholar cannot neglect the Targums and the Talmuds. The historian, the philosopher, and scientist have an interest in the rabbinical literature of the Middle Age. On what grounds of justice or right can the professors in the colleges and universities throw all the responsibility for these studies upon Christian theological seminaries or Jewish rabbinical schools? The colleges and the universities have a joint interest with the theological faculty in the study of the texts of these writings, upon which so much depends for the textual criticism of the Holy Scriptures.

(3) The text of Scripture having been determined, the student next devotes his attention to the higher criticism, or literary criticism, of Holy Scripture. The criticism of Holy Scripture has been crippled because of lack of support in our colleges. If the universities had trained the present generation of ministers in the literary criticism of the Greek and Latin classics, and of the early English, German, French, Italian, and Spanish literatures, the outcry at the literary criticism of Holy Scripture would have been avoided, and the church would not have been torn by a great controversy. Some of our best universities are doing the work of textual, or the lower criticism, of literary, or the higher criticism, and of the historical criticism; but, so far as can be determined from the catalogues, they still lag behind the universities of Europe in the entire field of criticism. There will be no peace in the church until the literary problems of Holy Scripture are all thoroughly worked out and solved. In some respects the universities could do this work better than the theological schools-the professors being free from those denominational and schismatic influences which obstruct the pathway to all scientific study of the Bible.

(4) The exposition of Holy Scripture is a work of the utmost delicacy and difficulty. This is due in part to the difficulty of the themes, the obscurities of the symbolism of the prophetic writers, the ancient modes of reasoning and rhetorical expression, and the unfamiliar environments of the writers. But the chief difficulty is due to the obstructions which have been 
placed in the way of the student by the traditional way of looking at the Scripture. These obstructions are, however, gradually being removed, and the exposition of the Scripture is in our times making such great and rapid advances that it is exceedingly difficult even for the teacher of the Scriptures to keep pace with it. It is of great importance to be able to expound the original Hebrew, Aramaic, and Greek Scriptures ; but it is also important to be able to expound the English Bible. The theological schools have not given undue attention to the former, they still lag behind the ideal; but they certainly have neglected the latter. One of the greatest needs of the theological school at the present day is a thorough study of the English Bible and training in its exposition. The university has a common interest with the theological school here.

(5) You will find on the catalogues of the theological seminaries biblical history, that is, Old Testament history, life of Christ, the apostolic church, and the like. But so far as one can see from the catalogues these are taught in methods and ways which have long been antiquated in Europe; and without having appropriated the higher criticism and historical criticism of the Bible they are in great measure unscholarly and false to truth and fact. Moreover, biblical geography, the natural history of the Bible, and biblical archæology need separate treatment in independent and optional courses. The contemporary history of the Old Testament and the New Testament are new and fresh lines of study from which rich fruit may be gathered. Here are great opportunities for the university to aid the theological school.

(6) The crown of biblical study is biblical theology. This is a modern study which has had a century of development in Germany but which is a recent arrival in America. The aim of biblical theology is to ascertain the religious, doctrinal, and ethical views of each biblical writer, to arrange them in the order of their historical development, and to state the result of the process as the sum of the biblical teaching. The working out of the discipline of biblical theology will eventually result in the clear recognition by dogmatic divines of the sources of 
their opinions. It will clearly appear that the major part of all dogmatic theology is speculative, the minor part biblical. So soon as this is recognized then the line may easily be drawn between that which is of divine authority and that which has been established on merely ecclesiastical or scholastic warrant.

II. Church History. - There are many important divisions and branches of church history.

(I) The church historians have given their chief attention to the ancient church and the period of the Reformation. The middle ages and the modern church have been neglected and commonly overlooked. The field is indeed too vast for any one man.

(2) The historians have worked on the great lines of church history. Accordingly the Greek church and the oriental churches have been too much neglected in the interest of the Latin church, and the comprehensiveness of the church narrowed thereby. The minor sects of the Reformation have been neglected until recent times. They are now seen to be the precursors of great modern movements in Christianity. So soon as the sources of history were searched by historical criticism many important fields of study were marked out, such as Christian inscriptions, Christian archæology, monumental theology, patristics, diplomatics, symbolics, and the like.

(3) Symbolics is one of the most fruitful branches of theology at the present time - for on its right hand stands its youngest child Irenics who is outshining at present the older brother Polemics on the left. Through the neglect of symbolics all the Christian bodies have in a measure drifted from their symbols into traditional opinions and practices. The symbols define the orthodox faith of the denominations and of the national churches; and the ancient creeds set forth the one catholic faith of the church. The study of this unity and variety opens up one of the pathways to church unity.

(4) Efforts have frequently been made for the study of patristics in seminars, but the lack of time and teachers has stood in the way. There ought to be opportunity for the study of the Greek, Syrian, and Latin Fathers in the original in all of 
our universities and seminaries. There ought to be opportunity for some theological students to study the apostolic fathers, the Apology of Justin, and the history of Eusebius and the great theologians of the early church in their original Greek. The Syriac hymns, homilies, and commentaries of Ephraem, and the histories of Bar Hebraeus are fruitful for the theologian and ought not to be neglected. If Ephraem had been better known the crude eschatology of later times might have been avoided and a sounder exegesis would have prevailed in the Christian church. The reading of Augustine's De Civitate, Anselm's Cur Deus Homo, the Summa of Aquinas, the De Imitatione Christi and other rich specimens of the theology of the Latin fathers, schoolmen, and mystics are of incalculable value to the theologian which nothing can replace. It is one of the blessings of the Oxford movement that it led to a better study of the fathers. But the American universities and theological schools are far behind the British and the German in this regard.

(5) Monumental theology was greatly advanced by Dr. Ferd. Piper of Berlin, and the study was prosecuted by Dr. Bennett in this country, whose valuable work on Christian Archaology was the fruit of years of faithful study. The Oxford movement tended in that direction, but apparently it used the monuments of Christian history for purposes of ritualistic worship rather than for the sources of the history of the church. The schools of art and architecture might aid the theological seminary in this department. No one who has not studied in this field can estimate the value of the Christian monuments for purposes of history. The witness of the catacombs and the tombs of the ancient churches with their mosaics and statuary and paintings, their baptistries and sacred vessels - give us the history of the church in its organization, in its ritual, in its doctrine, and in its life; sometimes in the cold outlines of sculpture, then in the terse language of inscription, the massive proportions of architecture, and the rich colors of painting.

(6) Church history reaches out in all directions and unfolds into an indefinite number of departments, for everything in a measure belongs to Christian history. The history of dogma is 
one of the great divisions of topics of church history according to the scheme of Neander, a department cultivated by few scholars in our country or England, but chiefly in Germany. It is indispensable for a sound system of Christian dogma. It has been recently transformed by the labors of Hatch and Harnack who have in a marvelously brilliant way separated the genuine Christian material from the ethnic types and forms of thought.

(7) The history of Christian institutions is of increasing importance in recent years. It sheds abundant light, and indeed searching, critical, and destructive light, upon those institutions which are merely traditional; but penetrating, interpreting, illuminating light upon those institutions which are truly historical.

(8) The history of the papacy discloses the secrets of its power, the reasons for its permanency, the grounds for hope in its transformation.

(9) The history of councils gives the great landmarks of ancient ecclesiasticism, the successive clashing of forces, the shocks which produced the fractures in Christendom and the avalanches of denominationalism. The history of modern synods, councils, and assemblies continues the story and works out in the realism of history the principles of division and the lessons for the reconciliation of unity with variety in organization, liberty of conscience with canonical obedience, fidelity to the voice of the Holy Spirit with consent to the decisions of the church.

(ro) The history of the Inquisition unfolds the story of ecclesiastical persecution, detects its primary fallacies, and enables us to trace the serpentine windings of its fundamental principle as it reappears in other churches in our day and generation.

(I I) The history of the monastic orders shows us the working out of the principle of self-sacrifice and consecration to Christ and his church in those magnificent enterprises which are in some respects the beacons of ages which would have been dark and barren without them. The modern orders have avoided the ancient corruptions, but have not in all respects avoided abuses of their own. And yet the Jesuit order saved and in a measure reformed 
the Latin church and has borne the banner of the cross with Christian heroism into the most distant parts of the earth. The Paulist fathers have exerted a great influence for good upon the American type of Latin Christianity. Modern protestantism owes much to the Kaiserswerth deaconesses and the Knights of St. John and the kindred Anglican orders. The Salvation Army is a new military protestant order which in some respects puts to shame the ancient Templars. I am convinced that the modern church needs still other and more churchly orders which will consecrate themselves to the specific demands of our modern world.

(I2) The history of the religious guilds is also of increasing importance in the light they shed upon the modern guilds for Christian work. It seems as if the Christian world were entering upon a period which bears the same relation to the great Reformation as the Middle Ages did to Nicene Christianity.

(13) The histories of the sects and of the hundreds of Christian denomination and societies give important contributions from each one of them as it works out an important principle either to absurdity, decay and death, or to a rich and fruitful life. The test of history is the judgment of God to which all should give heed.

These will indicate in some measure the branchings out of church history. How is it possible for one teacher to do all this vast work of investigation and of instruction. It is a department in which several professors should work together. Will the university rise to this ideal in coopperation with the theological school, or will it be necessary for the theological seminary itself to rise into a theological university and cover the ground of Christian history?

III. The System of Theology.-The system of theology embraces the three great divisions, Religion, Dogma, Morals.

(I) Religion is the primary department of the system of theology. It was buried in dogma by the older theologians. It has emancipated itself in part and it already exhibits a vigorous and fruitful life.

(a) We begin with the history of religions which will embrace 
in their historic order and place all the historic religions of mankind. This involves a study of all the sacred books of the great religions and inquiry into the customs and practices of the lesser religions. It seems to be necessary for the university to do this preparatory work. The gathering of all this vast material of the history of religions must be done by a large number of university men. But the trained theologian may gather up all this material and make it into a history of religions. The religion of Israel and its fulfillment in the religion of Jesus cannot be thoroughly understood until it is set in the midst of the historic development of the other religions of the world.

(b) The philosophy of religion is another modern study of increasing importance. Here religion and philosophy come into helpful contact. Religion must be rooted and grounded in the nature of man, in the variety of temperaments and races of men, and its development must be explained in accordance with its historic environments and the civilization of which it forms a part. It is of great importance to know what place Christianity has in the philosophy of religion.

(c) Comparative religion springs from the results of a history of religion and the philosophy of religion. It is of importance to know how Christianity stands the test of comparison. This discipline shows the essential features of all religion, it eliminates one religion after another as we rise in the scale of religions until at last Christianity is seen grandly towering above all in its heavenly uniqueness.

(d) The theologian who has made these preliminary studies is prepared to learn from biblical theology the religion of the Old Testament and the religion of the New Testament; and from church history the religion of Christianity in its unity and variety. He may then for the first time with safety construct a firm and abiding system. He may put it in the form of apologetics on the one side or of polemics on the other; but he will act more wisely if he construct it into a system of Christian religion.

(e) Apologetics is now and long has been the bane of modern theology. Self-constituted defenders of the faith, Uzzahs 
trembling for the ark of God, religious demagogues eager for notoriety have raged in this field. Many eminent scholars have endeavored to construct the defense of Christianity on a solid basis and entrench it in defensible lines, but the history of modern apologetics has been a mêlée rather than a holy war. Christianity is its own best defense. The problem is to state it truly and accurately - to remove from it all the stains and accretions of mere tradition and to exhibit it in its historic evolution under the impulses of the divine Spirit.

"For Truth has such a face and such a mien As to be loved needs only to be seen."

This word of Dryden applies to all truth, much more, then, to Christ and Christianity. To know Jesus Christ and his religion,to hold them before the world in their simple truth and their profound reality,- to set them on the pinnacle of exact and comprehensive scholarship, in the midst of all the religions of history, and of all the speculative systems of philosophy, in the blaze of universal knowledge, that is to see the Christ invincible and regnant and his religion the universal religion.

(2) Dogma.-The central division of the system of theology is dogma, the system of the faith of the church. I have no sympathy with the prevalent hostility to dogmatic theology. There are excellent reasons for the hostility to the systems of the sectarian theologians who have dominated modern theology. But it is necessary that we should learn that these systems are misstatements of the Christian system of dogma and are not the Christian system itself. These systems are speculative elaborations of traditional dogma with a capricious use of such modern learning as seemed appropriate and a studied neglect of everything that could not be assimilated. The system of dogma of historic Christianity, the one catholic faith of Christ's church, has been overwhelmed, obscured, and buried under the mass of provincial elaborations and sectarian interpretations. The reconstruction of the system of theology, which is so greatly needed, is to be accomplished by the elimination of all material that is merely speculative, all that is merely provisional, all that has sprung from the circumstances of a single denomination, or 
from a peculiar epoch of history, in order to gain that which is the sacred deposit of historic Christianity, the one holy catholic faith of the church.

(a) It is necessary to begin with a study of the doctrines of the historic religions. The three great topics of dogmatic theology are God, man, and redemption. It is important that we should learn what is the Greek idea of God, what the Roman idea of man, what the Assyrian conception of redemption. We need to learn the common faith of mankind as expressed in all the historic religions and to distinguish the special faith of each one of them. The doctrines of God and of man and of redemption as they are derived from Holy Scripture, placed in the midst of the faiths of the ethnic religions, appear in new light and significance as we rise from the common faith of mankind through all the variations to the unique faith of Holy Scripture and of the Catholic church.

(b) Philosophy has its contribution to make to dogmatic theology, so important, indeed, that without it a system of dogmatic theology is impossible. (a) The reason has its place in theology. Its voice cannot safely be ignored. Who is the God of reason? What sort of a God speaks the imperative of the conscience? How does he satisfy the religious feeling? Do his existence and activity explain the constitution and order of nature? The God of the system of theology must be the God of a sound and comprehensive philosophy. The God of the Bible and the church may be beyond the comprehension of the reason and the utmost attainments of the human conception, imagination, and fancy ; but there cannot be any valid doctrine of God which the reason excludes, which the conscience condemns, and from which the religious feeling shrinks, and which the conception and imagination cannot frame without violation of the laws of human thought. The God of the sectarian theologian is not the God of modern philosophy. The dogma of God should be so reconstructed that the Godof dogma and of philosophy shall be one and the same God.

$(\beta)$ The anthropology of dogmatic theology must embrace all the results of modern psychology. The dogmatic theolo- 
gians have always constructed their doctrines of man in accordance with the psychologies of their own age. Every dogmatic statement about man, whether in the treatise of the theologian or in the confession of faith or catechism, bears with it psychological conceptions. Modern philosophy has made enormous strides in the department of psychology. This involves an entire reconstruction of the doctrine of Man in the dogmatic system. Even in the Bible itself we must take account of biblical psychology in considering the biblical doctrine of man. It is necessary in the history of dogma to distinguish between the psychological form of the doctrine of man and the substance of the dogma, the sacred deposit itself. The problem for dogmatic theology in our age is to take that sacred deposit and reconstruct it in the forms of modern psychology.

$(\gamma)$ In the whole immense field of the doctrine of redemption, the ethical philosophy of modern times must be considered. The traditional dogma offends against ethical philosophy in many respects in its doctrines of the atonement, and of justification and of imputation and of good works. The substance of the doctrine is true and real as the legitimate product of Christian experience in the evolution of dogma in the church - the sacred deposit is there behind these dogmatic modes of statement. The modes of statement must be changed. The form of the dogmas must be reconstructed so as to harmonize with ethical philosophy. In all this great field of the relation of philosophy to dogma there is great weakness at the present time, especially in our country. Flint and Fairbairn are working in this field in Great Britain. Henry B. Smith started out in that direction in his address on "Faith and Philosophy," but the circumstances in which he was placed stayed him from making much progress in it. Here is a magnificent field for the future in which the department of philosophy in the university has as great responsibility as the teachers of dogmatic theology in the theological school.

(c) Biblical theology makes its contribution to dogmatic theology in the form of biblical dogmatics. Biblical dogmatics will give the complete statement of Holy Scripture as to 
any dogma which may be under consideration, eliminating from it all that is temporal and circumstantial in the evolution of the doctrine in the successive stages of divine revelation, and presenting the holy, eternal substance of the doctrine as the divine word to man.

(d) Church history gives its contribution to the system of dogma into the hands of historical dogmatics. The history of dogma, the history of councils, the disciplines of symbolics and patristics, all have important contributions to make. The problem is essentially the same as that in biblical dogmatics, to eliminate the sacred deposit of the catholic faith of Christ's church, which it has kept and unfolded under the guidance of the Holy Spirit, from all that is temporal, provincial, local, denominational, and sectarian. This field was a favorite one of my greatest teacher, Isaac A. Dorner. In his system of the Christian faith, his criticism of the historic statements of the faith and the discrimination by which he separates the essential substance from the formal envelope, are to my mind the most fruitful parts of his work.

The statements thus far made are sufficient to show the reasons why dogmatic theology has fallen into contempt not only on the part of the people who dislike to hear of it in the pulpit, but also of students for the ministry and of ministers themselves who are weary to death with its scholasticism and merely traditional modes of statement. An immense amount of preparatory work is necessary before the system of dogma, the system of the faith of Christ's church, can be successfully reconstructed. But so soon as the man of faith and intellect shall stand up at the call of God and use all the material from the history of religions, from philosophy, from biblical dogmatics and historic dogmatics, and with constructive genius organize all this material into a system - then we shall have a system of theology that will be fresh, grand, magnificent, inspiring, and transforming in its influence. It probably will accompany the coming reformation of the entire church.

(3) Ethics.-The final and culminating part of the system of theology is the system of Christian ethics. This is a modern 
theological discipline which has been highly cultivated in this century on the continent of Europe, but has received little attention until recent times in Great Britain and America.

The system of Christian ethics depends upon the same preparatory work as Christian religion and Christian dogmanamely, the ethics of the religions of the world, the ethics of philosophy, the ethics of the Bible, the ethics of Christian history. Only on the basis of all this preliminary and preparatory work can a true and abiding system of Christian ethics be organized.

One of the most remarkable developments in recent years has been in the field of ethics as it branches out into such extensive reaches that it seems impossible to keep up with its expanding lines, which ultimately comprehend all things. We are coming into an ethical period of the world, and especially an ethical epoch in theology - for everything in the world will ere long be considered chiefly in its ethical relations. Christian ethics goes wherever ethics goes. There should be no separate system of Christian ethics. In the order of historical development you may distinguish Christian ethics from the ethics of other religions. In the department of philosophy you may give ethical philosophy which in its lower stages may not be Christian. In practical ethics you may establish yourself on preChristian ground and on principles which underlie Christianity and other great religions as well-but so far as your ethics is true, so far as it is real, so far as it is substantial, it is yet Christian, for Christian ethics includes it in its sweep-you are simply taking your ground on the lower planes and more elementary principles which Christian ethics recognizes and maintains. Where will you go and escape from Christian ethics? - to the individual ? - Christian ethics claims every man, woman and child in the world :- to the family? - Christian ethics gives the law to the father and child, brother and sister, husband and wife, servant and master, and presents the model for all these relations in the heavenly father, and in the Christ who is at once the son and the brother, the servant and the husband:- to society?-Christian ethics enters into every phase of society in order to transform it. 
Men are saved according to Jesus not by their profession of faith or knowledge or opportunities or birthright, but because Jesus can say to them, "I was an hungered and ye gave me meat, I was thirsty and ye gave me drink, I was a stranger and ye took me in; naked and ye clothed me; I was sick and ye visited me, I was in prison and ye came unto me." He who knows not Christ by personal acquaintance and yet does these things is yet a Christian - those who know of Christ and do not these things are not accepted as Christians by Christ himself. Christian ethics must, if it would justify its name, enter with relief into all the problems of modern society. Hospitals, schools, public charities, college and university settlements, guilds and labor organizations, public parks, lavatories - everything that would improve the condition of society is in the field of Christian ethics.

The church and the state cannot be so separated that the one may safely ignore the other. The church is in the state in a sense-but there is also a sense in which the state is in the church. The church is larger, more comprehensive in time and in place and area of influence. The Latin church rises on this principle to a dominion over all the states. Protestantism, while it recognizes the supremacy of the state in all matters which come within certain definite lines of jurisdiction, yet forbids the state from intrusion into other lines of jurisdiction where the church is supreme. The state is free from the dominion of the church, but it is not and must not be free from the moral obligation to adhere to the principles of Christian ethics. Christian ethics illumines all the activities of the state with the light of Christian principles and with Christian examples. There cannot be one ethical principle for the state, another for the church, and still another for the individual. Where the lines of duty coincide that which is wrong for the one is wrong for the others - that which is right for the one is right also for the second and the third. Christian ethics will not permit the state to steal any more than one of its own citizens. It will not permit the state to lie any more than the church - it will not permit the state to make idolatrous worship any more than the churchman. Here 
is a fruitful field of investigation which, from the? circumstances of our century, can best be made in the university.

The church falls within the range of Christian ethics also. The church has been considered too much from an ecclesiastical point of view-less from a doctrinal point of view - still less from an ethical point of view. One of the most fruitful studies that could be made at the present time would be to trace ethical principles through all the varied forms of the organization and activity of the church, to test them all in the mirror of the life and teachings of Jesus. It is easy to see that the result would be such a transformation that the church would hardly know itself. Christian ethics has the unique advantage of Jesus Christ as its teacher, exemplar, and ever-living guide. Looking to him as the holy King reigning on his throne, from which he directs all the evolutions of man and nature towards the accomplishment of the sublime purpose of grace, Christian ethics enlarges its scope until it takes in the whole realm of universal nature, the vast reaches of intelligences in other worlds than ours - it expands beyond the limits of this world and this life and comprehends the church of the dead as well as the living and the whole sweep of the divine government of our universe from the morn of the first creation until the day of ultimate doom. Christian ethics rises to this comprehensive positionand all its principles and methods are in the category of eternity and in the measures of God the Father and Jesus Christ his Son. Inscribed upon the portals of Christian ethics are the words: "Be ye perfect as your father which is in heaven is perfect." Enthroned at the center of all its avenues is the Holy Messiah.

Christian ethics is only in its beginnings in our theological seminaries. Some of them have established chairs of Christian sociology or of applied Christianity. There may be room in a theological university eventually for several professors in this department. But the coöperation of seminary and university will lead eventually to the best results.

IV. The church.-The church is an organization of Christians under the headship of Christ with ministers appointed by Christ to lead the people in worship, life, and work. The doctrine of 
the church is wrought out under the Christian system of theology. We have now to consider the church as an organization.

(I) It is organized as a government with an historical constitution and an historical ministry. The church is one in its divine constitution and plan. Every division in the church has been the result of a sin of violence either on the part of the church itself or of the separating bodies. The sins of the fathers have been visited on the children through many generations. Eventually all the wounds of Christ's church will be healed, all schisms repaired, and its divine plan and constitution carried out in reality and entirety. The historic ministry of the church will eventually be eliminated from all denominational and schismatic accretions. When the mother churches repent of their sins of excision and open the doors of welcome, then the exscinded daughters will not long remain absent from the maternal home. This is the great problem in church government at the present time, to find the basis in the historic ministry for a unity which will be consistent with many various modes of adaptation to the needs of the different races, nations, and communities.

(2) The historic church has its canon law, the formulation of the legal experience of centuries. The canon law lies at the basis of all the canons, church orders, and church disciplines of the national churches of modern Europe and of the separating and dissenting denominations. The study of canon law is of very great importance for theologians at the present time. So long as it is neglected the denominational disciplines are hanging in the air apart from the historic law of the church.

(3) The church is organized for worship under the lead of the historic ministry. Sacred places have to be considered and Christian architecture becomes important. Sacred times demand attention - the Sabbath, the Christian year, thanksgiving days and fast days and their proper observance. Sacred things come into view - the baptistries - the holy table and its vessels the use of painting and statuary, missals, illuminated texts and pictorial windows. The worship of the churches is dependent upon the ordering of ceremonies, whether we think of the elaborate worship of the Greeks or the bare worship of the Friends. 
Liturgies must be studied, and that whether we use forms of prayer or the traditional language of extemporary devotion in accordance with an order of worship. Sacred song and music must all be investigated that Christian worship may be enriched by melody and harmony. The Oxford movement has been a blessing to the entire English-speaking world by its enrichment of Christian worship in all denominations. Few of these studies in the department of Christian worship which have been mentioned are pursued in our seminaries. Little if any attention is given to these matters in most of the theological schools. The university might engage in some of them for the common welfare.

(4) The church is organized for purposes of instruction This instruction is given in various grades. The primary is catechetics - the training of the young in the essential principles of the Christian religion in preparation for the sacred mysteries. The discipline of catechetics includes a study of the historic catechisms of the church and of the history of catechetics, and it results in the principles and methods of a practical catechetics. Cathechetics has been enlarged in the last century so as to embrace the modern Sunday school which aims especially to give elementary training in Holy Scripture; and the charity and industrial schools which are essentially mission schools for the training of the children of the poor and the outcast. Great attention is given in our country to the Sunday school; but little attention, so far as I know, has been paid to catechetics in its original and most important work.

(5) The training of the people is chiefly from the pulpit and through the preacher. The discipline which has to do with this department is homiletics. More attention is paid to this department in our American theological schools than to any other in connection with the church itself; and yet the history of preaching is commonly neglected.

(6) The training of the ministry is a department which needs more thorough study and comprehensive views. The training of ministers in school, college, seminary, and university has to be carefully considered. The training of deaconesses and lay workers of various grades is opening up new problems. The min- 
istry of the protestant churches will have to follow the example of the more ancient churches and enlarge itself by the additions of various grades of trained helpers who should be an official part of the organization, even if it is necessary to distinguish them from the orders of the historic ministry. The question of aid to students for the ministry is also a burning one at the present time.

(7) Pastoral theology or the care of souls is taught in most of our theological schools. But the history of the discipline is ordinarily neglected and it is usually taught in unscientific methods, and often in the form of practical hints from the retired ministers who usually give instruction in this department.

(8) The church should be organized for Christian work The Roman church is stronger here than the national churches of protestantism and their dissenting children. The Roman church took up into itself organizations of every variety of form for aggressive work. She is doing the same thing at the present time. Any new organization for good work may receive the sanction of the church and become incorporated into the church. It has ever been difficult for protestantism to do this. Accordingly the great organizations for good work among protestants are commonly outside the churches, although in general sympathy with them. The Church of England and the Church of Scotland have overcome this defect in a measure by the organization of churchly guilds, and institutions for deaconesses and orders of various kinds for Christian workers. These point the way for the future practical development of the church. The guilds and churchly institutions have to supplement the pastoral work of the ministry in teaching the ignorant, in relieving the poor, in comforting the troubled, in reforming the depraved, in alleviating suffering and in caring for the dying and the bereaved -in all those multitudinous ways of doing good which are opening up in all directions for Christian men and women. The theological schools are weak here - some of them, are however, rising to the situation and are equipping themselves for this work. The universities have an important field of coöperation with them.

(9) The church is also organized for the propagation of the gospel in the work of missions. The work of foreign missions, 
the work of home missions on the frontiers of our country, the work of city missions, are three well-organized departments of missions.

Great advance has been made in recent years in the practical work of missions; but the church lags behind its tremendous opportunities in our age, when the whole world is open for evangelization. The church is wasting her energies and abusing her vast resources in inter-denominational strife, when it should economize them and concentrate them for the conversion of the world. Instruction in missions in theological schools has not kept pace with the advance on the practical side, and is far from holding up the great ideals of Christianity. Few theological schools give systematic instruction in mission work. Nowhere is adequate training given.

We have gone over the several departments of theology without any effort at completeness, and have seen many fruitful branches reaching out in all directions, entwining with all departments of human knowledge and covering the whole of human life. No theological school at present existing pretends to cover the whole ground of theology. Only by a combination of several of them would it be possible at the present time to approximate the demands of the science. Will it be practicable for our theological seminaries to enlarge themselves so as to cover this vast field? It is impossible for all of them to do it. A few of them might, by doubling and trebling their resources, rise with enthusiastic effort towards its accomplishment. But it is impossible that any of them can do it without the coöperation of the great universities; for only in the great university can the highest ideals of theology be attained where a truly scientific and truly practical theology, free from denominational restraint and bias, shall pervade, influence, and point all the energies of the university; and where a theological faculty will coöperate with a legal, medical, and philosophic faculty, and so push university work into all the reaches of theology, and explore the whole realm of universal knowledge and universal life. 